\title{
Coupled Geochemical and Hydrological Processes Governing the Fate and Transport of Radionuclides and Toxic Metals Beneath the Hanford Tank Farms
}

June 16, 2004

Philip M. Jardine

Oak Ridge National Laboratory

P.O. Box 2008

Oak Ridge, TN 37831-67038

865-574-8058

jardinepm@ornl.gov

Scott E. Fendorf

Stanford University

Dept. Geological and Environ. Sci.

Palo Alto, CA 94305

650-723-5238

fendorf@stanford.edu

509-373-6948
Melanie Mayes

Oak Ridge National Laboratory

P.O. Box 2008

Oak Ridge, TN 37831-6038

865-574-6398

mayesma@ornl.gov

Students / post grads: 2 doctoral candidates

2 undergraduate student

1 post-masters

1 post-doctoral

This annual report describes $1.5 \mathrm{y}$ of progress on a 3 y project. The project addresses the goals of the Environmental Management Sciences Program (EMSP) that seeks innovative basic research to benefit cleanup technologies and decision-making strategies for contaminated environments. Our project specifically addresses Hanford research needs in subsurface science by contributing to the objectives of the Tank Farm Vadose Characterization Project and the 200 Area Remedial Action Project which are components of the Hanford Site Groundwater/Vadose Zone Integration Project (Integration Project). The work described within is intended to advance the technological and scientific needs associated with the long-term management of the enormous in-ground inventories of ${ }^{235 / 238} \mathrm{U},{ }^{99} \mathrm{Tc}$, ${ }^{60} \mathrm{Co}$, and $\mathrm{Cr}(\mathrm{VI})$ present at the Hanford site. We believe that scientifically defensible predictions of contaminant transport and strategies for remediation must be based upon a field-relevant understanding of coupled hydrological and geochemical processes that control subsurface contaminant fate and transport. This research project investigates the migration of ${ }^{235 / 238} \mathrm{U},{ }^{90} \mathrm{Sr},{ }^{60} \mathrm{Co}$, and $\mathrm{Cr}(\mathrm{VI})$ in undisturbed sediments from the Hanford site using realistic experimental protocols designed to delineate complex hydrological and geochemical processes controlling contaminant movement. The specific research goals of the following proposal are: 
- to provide an improved understanding of how preferential vertical and lateral flow, and the formation of immobile water influence the transport of radionuclides and toxic metals in heterogeneous, laminated sediments.

- to quantify the rates and mechanisms of radionuclide and toxic metal interaction with the solid phase under various hydrologic conditions.

- $\quad$ provide new insights into how physical and mineralogical heterogeneities (e.g. stratification, pore regime connectivity, mineral composition along flowpaths) influence contaminant retardation and the degree of geochemical nonequilibrium during transport.

The overall research products will be (1) knowledge and information in previously unexplored areas of vadose zone fate and transport to support EM's performance/risk assessment and decision-making process for Tank Farm restoration; and (2) improved predictive strategies for assessing the transport rate and fate of ${ }^{235 / 238} \mathrm{U},{ }^{90} \mathrm{Sr},{ }^{60} \mathrm{Co}$, and $\mathrm{Cr}(\mathrm{VI})$ beneath the Hanford Tank Farms. Since this project will unravel fundamental contaminant transport mechanisms in complex porous media, the results will assist in improving our overall conceptual understanding and predictive capability of a variety of vadose zone issues within the DOE system (e.g. INEEL and Sandia).

\section{$\underline{\text { Technical progress }}$}

\section{FY02 technical progress}

Significant findings regarding hydrologic processes in sediments beneath the tanks:

(1) The saturated and unsaturated hydraulic conductivity of cores acquired parallel to lithological layering was an order of magnitude more rapid than the conductivity of cores acquired perpendicular to lithological layering. Thus, lateral flow beneath the tank farms is a strong contributor to the spread of contaminants. Also, the conductivity of fine grained cores was an order of magnitude slower than core acquired in sandy media.

(2) The transport of the three nonreactive tracers at different degrees of unsaturation showed essentially no difference in breakthrough patterns when flow remained unrestricted along continuous lithological features as is the case for the horizontal cores. This suggested that physical nonequilibrium conditions were not occurring during lateral flow in these sediments. Thus matrix diffusion processes are not contributing to the attenuation of waste being released from the Hanford tanks allowing for more rapid transport rates beneath the tank farms.

(3) However, when flow is partially restricted by lithologic discontinuities as is the case for the vertical cores (e.g. alternating coarse and fine layers), perched water tables develop resulting in unstable wetting fronts and the prevalence of preferential flow. The early breakthrough and significant separation of tracer in the effluent suggest that large pockets of immobile water develop creating a condition of physical nonequilibrium between flowing domains and immobile domains. From a contaminant transport perspective this process is advantageous since the presence of large pockets of immobile water will significantly impede the vertical migration of waste being released from the Hanford tanks. 
Significant findings regarding geochemical processes in sediments beneath the tanks:

(1) Batch and repacked column studies have shown that U, Cs, and Sr are strongly bound to the various sediments beneath the tank farms even under conditions where the solid phase $\mathrm{pH}$ is as high as 8.4. Modeled partition coefficients for $U$ were on the order of 10 to $15 \mathrm{~cm}^{3} / \mathrm{g}$ corresponding to retardation coefficients of 35 to 50 . Modeled partition coefficients for Cs ranged from 30 to $90 \mathrm{~cm}^{3} / \mathrm{g}$, with the Hanford formation exhibiting a significantly larger retention capacity for the Cs versus the Ringold formation. Ternary exchange isotherms and column displacement experiments for the U-Cs-Ca system showed limited competitive sorption effects suggesting independent mechanisms controlled $U$ and Cs sorption. This is consistent with experimental evidence showing that $\mathrm{U}$ sorption is often controlled by subsurface Fe-oxides and Cs sorption is often associated with the interlayer spaces of 2:1 phyllosilicates. On the other hand, the Sr-Cs-Ca system shows extensive competition for sorption sites.

(2) X-ray Absorption Spectroscopy (XAS) suggested that inner-sphere ternary carbonate complexes formed on Fe-oxides in sandy Ringold sediments while sorption of sheet silicates was the primary sorption mechanism in silty Ringold sediments. These data underscore the importance of understanding the sediment mineralogy to accurately access the fate and transport of uranium in the environment. The implications of the sorption reactions are that the downward vertical migration of $U$ beneath the tank farms will be significantly slowed by interfacial geochemical sorption reactions.

(3) Reactive transport of Sr in undisturbed Hanford cores and U in undisturbed consolidated material of the Plio-Pleistocene unit have also been conducted. The Plio-Pleistocene unit was not conducive to either preferential vertical finger flow or to lateral flow, as no tracer separation (Br/PFBA/PIPES) was observed under our experimental conditions. The absence of distinct sedimentary bedding in the Plio-Pleistocene probably accounts for this observation. Our results therefore suggest that physical nonequilibrium processes will be minimal in the Plio-Pleistocene unit. Reactive transport of ${ }^{235 / 238} \mathrm{U}$ through the Plio-Pleistocene unit exhibited evidence of nonequilibrium, possibly influenced by kinetics or multi-site/multi-species reactivity. Sorption of ${ }^{235 / 238} \mathrm{U}$ was significantly enhanced under equilibrium conditions when compared to transport or flowing conditions, which suggests kinetic effects on sorption. Transport experiments were conducted in an atmosphere representative of subsurface conditions $\left(1 \% \mathrm{CO}_{2}\right)$, which resulted in the formation of a stable uranyl-carbonate complex. Therefore, it is also likely that the large complex may have different affinities for subsurface sorption sites. Transport through the PlioPleistocene unit has demonstrated the presence of geochemical nonequilibrium while physical nonequilibrium processes were minimal, thus resulting in a greater understanding of the relevant mechanisms governing contaminant interactions in the Hanford subsurface.

\section{FY03 technical progress}

Collection of additional cores of undisturbed Hanford sediments:

(1) Six large $(0.025 \mathrm{~m} \times 0.025 \mathrm{~m})$ undisturbed cores were collected at the Environmental Restoration Disposal Facility (ERDF) in May for the purpose of conducting additional transport experiments. Three cores in the vertical direction and three cores in the horizontal direction will be used to quantify lateral and vertical flow as a function of water content. Six small $(0.008 \mathrm{~m} \times 0.006 \mathrm{~m})$ cores in both vertical and horizontal directions were collected for the purpose of determining the capillary pressure-saturation curve. Four small $(0.008 \mathrm{~m} \times 0.006 \mathrm{~m})$ cores were collected to 
examine the microscopic sedimentary pore structure of the sediments.

(2) Additional samples of Hanford sediments from a variety of boreholes around the Reservation (C3177, C3828, C3391, C4124, and B8810) were obtained from the Hanford Core Library. These sediments will expand our investigation of the Hanford subsurface to depths greater than, and lithologies different from our ERDF sediments, thus increasing the relevance of our work. Disturbed samples of these sediments have been used in batch and kinetic studies of Cr(VI) and $\mathrm{U}(\mathrm{VI})$. Intact samples of these sediments will be encapsulated into an apparatus for conducting unsaturated, reactive transport experiments using $\mathrm{Cr}(\mathrm{VI})$ and $\mathrm{U}(\mathrm{VI})$. This technique will allow us to quantify coupled hydrologic and geochemical processes in deeper cores in which the sedimentary pore structure is reasonably intact.

Significant findings regarding coupled hydrological and geochemical processes in sediments beneath the tanks:

(1) Repacked column experiments were conducted with SrEDTA ${ }^{-2}$ as it has been suggested that organic chelating agents may be responsible for the accelerated transport of strontium. Results indicated that the complex dissociated when contacted with the soil allowing strontium to be transported as $\mathrm{Sr}^{+2}$. It was determined that $\mathrm{Fe}(\mathrm{III})$-bearing oxides striped the EDTA from the $\mathrm{Sr}$ thus forming Fe(III)EDTA. This reaction is consistent with the larger association constant for Fe(III)EDTA ( $\log \mathrm{K}=25$ ) relative to SrEDTA ( $\log \mathrm{K}=10$ ). Therefore, $\mathrm{Sr}^{+2}$ was used in reactive transport experiments in unsaturated undisturbed Hanford cores. Unsaturated reactive transport of $\mathrm{Sr}$ in the undisturbed Hanford flow bedding parallel core shows strong reactivity which is consistent with batch and repacked column studies. The core was conducive to physical nonequilibrium processes (PNE) such as preferential finger flow and the formation of immobile water, as suggested by tracer separation and early breakthrough compared to saturated flow. The Hanford formation is a heterogeneous media of unconsolidated laminated coarse and fine sands that are interbedded with small-scale clay layering. It is this layering that causes PNE processes to develop under unsaturated conditions. Experimental results from batch and repacked columns predicted an increase in sorption of $\mathrm{Sr}$ in the undisturbed core due to the increase in sediment mass. However, accelerated transport of Sr was observed in the core possibly due to PNE processes such as preferential flow and media by-pass. Transport through the Hanford formation has determined the presence of physical nonequilibrium processes which influence the geochemical processes controlling reactive transport. These investigations are on-going.

(2) The mobility of $\mathrm{Cr}(\mathrm{VI})$ appears to be highly variable in Hanford sediments, with reduction capacity ranging from zero to significant depending on the availability of solid phase Fe(II). $\mathrm{Cr}(\mathrm{VI})$ was observed to be stable (i.e., no reduction to $\mathrm{Cr}$ (III)) over long time periods in the upper and middle Ringold Formations, and in the fine-grained Hanford from ERDF. These results were confirmed by the introduction of $\mathrm{Cr}(\mathrm{VI})$ into a large undisturbed ERDF core, in which complete recovery of $\mathrm{Cr}(\mathrm{VI})$ was observed. In contrast, the reduction of $\mathrm{Cr}(\mathrm{VI})$ to $\mathrm{Cr}$ (III) was robust in sediments from the C3177 borehole and in ERDF coarse-grained sediments, as evidenced by loss of aqueous $\mathrm{Cr}(\mathrm{VI})$. The contaminated sediment samples were analyzed using X-ray Absorption Fine Structure (XAFS) at the Advanced Photon Source (APS), which is a technique for determining solid-phase speciation and mineralogy. Reduction to $\mathrm{Cr}(\mathrm{III})$ was confirmed, and an association between $\mathrm{Fe}(\mathrm{II})$ and Ti suggested that ilmenite and other Fe(II)-bearing minerals acted as the reductants. Within the C3177 sediments, greater reduction to $\mathrm{Cr}$ (III) was observed in the more coarse-grained sample taken from 215' depth; while the lowest amount of reduction was observed in the more fine-grained sample taken from 150' interval. This coupled with the results from the ERDF samples suggests that there is a correlation between increasing grain size and 
reduction of $\mathrm{Cr}(\mathrm{VI})$ to $\mathrm{Cr}(\mathrm{III})$. The absence of reduced $\mathrm{Cr}(\mathrm{III})$ in the Ringold is probably related to its greater age, which resulted in transformation of the original $\mathrm{Fe}(\mathrm{II})$ sources to $\mathrm{Fe}(\mathrm{III})$. Additional work is ongoing to address the coupled hydrology and geochemistry of $\mathrm{Cr}(\mathrm{VI})$ mobility in the Hanford subsurface.

(3) The mobility of U(VI) in intact Ringold and Hanford sediments was tested in three unsaturated, undisturbed cores. Batch experiments suggest that the adsorption of $\mathrm{U}(\mathrm{VI})$ is controlled by $\mathrm{U}$ $\mathrm{CO}_{3}$ complexes at natural sediment $\mathrm{pH}$, and that adsorption was both kinetically-limited and nonlinear. Though the adsorption of $\mathrm{U}$ was significant $(\mathrm{R} \sim 10)$ under equilibrium conditions, retardation in the large unsaturated cores for equivalent residence times was small $(\mathrm{R} \sim 2)$. This is primarily a function of the hydrologic regime in which large proportions of reactive media are bypassed or kinetically-limited under unsaturated conditions, thus reducing available surface sites for U interactions. Subsurface contaminant distributions suggest a correlation between finegrained beds and $U$ retention, but it is uncertain if this is controlled by the hydrology (water content), geochemistry (mineralogy), or both (based on recently published subsurface inventories beneath the B-BX-BY and S-SX tank farms). The sensitivity of U adsorption and precipitation to changes in flow regime in intact sediments is a topic that needs much more exploration before all relevant mechanisms can be identified.

(4) The rates and mechanisms of Co(II)EDTA interactions with 20 Hanford area sediments were quantified in batch kinetic experiments, and it was found that capacity of the sediments to produce oxidized Co(III)EDTA ranged from zero to near 100\% . This has important implications regarding the enhanced mobility of ${ }^{60} \mathrm{Co}$ due to the high stability constant (log K 40) of the Co(III)EDTA complex. A good correlation $\left(r^{2}=0.9\right)$ was found between the sediment $\mathrm{Mn}$ content and the production of oxidized Co(III)EDTA, which will improve our predictive capability regarding the mobility of ${ }^{60} \mathrm{CoEDTA}$ in the Hanford subsurface.

(5) The transport of Co(II)EDTA through three large, undisturbed Ringold and Hanford cores was quantified under unsaturated conditions. The oxidation of Co(II)EDTA to Co(III)EDTA was dominant in the cores, which was consistent with the preliminary kinetic experiments. Differences in the amount of oxidized Co(III)EDTA were observed, depending upon the direction of flow relative to the direction of bedding. These results will be used to interpret the influence of coupled hydrological and geochemical processes in Hanford subsurface materials, and this work is on-going.

\section{Implications:}

The experimental and numerical results from this research will provide knowledge and information in previously unexplored areas of vadose zone fate and transport to support EM's performance/risk assessment and decision-making process for Tank Farm restoration. By unraveling fundamental contaminant transport mechanisms in complex porous media, we will provide an improved conceptual understanding and predictive capability of a variety of vadose issues within the DOE system. The implications of our work suggest that coupled hydrological and geochemical mechanisms will generally act to retard the migration of contaminants during transport through the vadose zone. The extent to which this occurs will depend upon the sedimentary pore structure, moisture content, the kinetics and the surficial geochemistry of contaminant interactions.

\section{$\underline{\text { Future accomplishments }}$}




\section{FY 2003:}

We have communicated these results to the site end-users, Ch2m HILL Hanford Group, and have submitted an informal proposal to CHG at their request. We expect to open a dialogue with the end-users regarding exact needs and directions for the future, which should enable us to strongly tailor our future experiments to suit their needs.

Our future studies will also focus on coupling the mechanisms of geochemical Cr(VI) reduction and $\mathrm{U}(\mathrm{VI})$ adsorption with the hydrology of the deep intact cores from the Reservation. Additional U(VI) equilibrium and kinetic studies will be completed on the Core Library sediments, and on clays isolated from the ERDF samples, which will provide additional geochemical parameters. The quantification of geochemical interactions with the isolated clays will provide insights into the connection between decreasing moisture content and increased and/or decreased retardation due to changes in moisture content. The relationship between intact core hydrology and sedimentology will be confirmed by performing dye tracing and core dissection on select Ringold and Hanford cores. Uranium and CoEDTA transport experiments will be conducted on the new Hanford cores from the ERDF, under a variety of hydrologic (\% saturation) and geochemical (caustic solutions) conditions. These experiments should provide new information regarding coupled hydrological and geochemical processes that are relevant to the Hanford vadose zone.

\section{Publications}

Peer-reviewed manuscripts (EMSP 70219 and 86911):

Jardine, P.M., S.C. Brooks, G.V. Wilson, and W.E. Sanford. 2000. Basic research strategies for resolving remediation needs in contaminated fractured media. (In) Dynamics of Fluids in Fractured Rocks (ed) B. Faybishenko. Geophysical Monograph 122, p. 389-400.

Jardine, P.M., G.V. Wilson, R.J. Luxmoore, and J.P. Gwo. 2001. Conceptual Model of Vadose-Zone Transport in Fractured Weathered Shales. (In) Conceptual Models of Flow and Transport in the Fractured Vadose Zone. U.S. National Committee for Rock Mechanics. National Research Council. National Academy Press, Washington D.C. p. 87-114.

C.C. Ainsworth, F.J. Brockman, and P.M. Jardine. 2000. Vadose Zone State-of-the-Knowledge: Biogeochemistry. (In) Vadose Zone: Science and Technological Solutions (ed.) B.B. Looney and R.W. Falta. Battelle Press, Columbus, OH, volume II, p. 829-947.

Jardine, P.M. 2002. Radionuclides. (In) Encyclopedia of Soil Science. R. Lal (ed.) Marcel Dekker, Inc. pp 1092-1097.

Bostick, B.C., M.O. Barnett, P.M. Jardine, S.C. Brooks, S.E. Fendorf. 2002. Uranyl surface species formed on subsurface media from DOE facilities. Soil Science Society of America Journal 66:99-108.

Mayes, M.A., P.M. Jardine, T.L. Mehlhorn, B.N. Bjornstad, J.L. Ladd, and J.M. Zachara. 2003. Transport of multiple tracers in variably saturated humid region structured soils and semi-arid region laminated sediments. Journal of Hydrology 275: 141-161. 
Pace, M.N., M.A. Mayes, P.M. Jardine, T.L. Mehlhorn, J.M. Zachara, and B.N. Bjornstad. 2003. Quantifying the effects of small-scale heterogeneities on flow and transport in undisturbed cores from the Hanford formation. Vadose Zone Journal 2:664-676.

Mayes, M.A., Pace, M. N., Jardine, P.M., Fendorf, S.E., Yin, X., Mehlhorn, T.L., Bjornstad, B.N., and Zachara, J.M. 200_. Coupled hydrological and geochemical processes governing the fate and transport of $\mathrm{Sr}$ and $\mathrm{U}$ in the Hanford vadose zone. (In review for) Subsurface Contamination Remediation: Accomplishments of the Environmental Management Science Program, T. Zachry and E. Berkey (eds.), American Chemical Society, Washington, D.C.

Pace, M.N., Mayes, M.A., Jardine, P.M., Yin, X., Mehlhorn, T.L. 200_. Uranium(VI) transport in sediments from the Hanford vadose zone (in review with Environmental Science and Technology).

Mayes, M.A., Pace, M.N., and Jardine, P.M. 200_. Coupled hydrological and geochemical processes governing the transport of U through the Cold Creek Unit, Hanford, WA (in prep for Soil Science Society of America Journal).

Mayes, M.A., Pace, M.N., Jardine, P.M., Mehlhorn, T.L. 200_. Lithologic factors governing tracer flow and transport in variably saturated undisturbed cores of laminated sediments (in prep for Vadose Zone Journal).

Pace, M.N., Mayes, M.A., Jardine, P.M., Yin, X., Mehlhorn, T.L., and Zachara, J.M. 200_. Strontium transport in undisturbed cores from the Hanford formation (in prep for Journal of Contaminant Hydrology).

Roh, Y., Mayes, M. A., Pace, M. N., Choi, S., Chorover, J., Phillips, D. H., and Jardine, P. M. 200_. Mineralogical characteristics of sediments at the Hanford site, WA (in prep for Soil Science Society of America Journal).

Mayes, M.A., Pace, M.N., Yin, X.L., and Jardine, P.M. 200_. The transport of chelated metals through variously-oriented, unsaturated intact cores of the Hanford and Ringold formations. (in prep for Journal of Contaminant Hydrology).

Mayes, M.A., Yin, X.L., Pace, M.N., and Jardine, P.M. 200_. Kinetics and mechanisms of Co(II)EDTA oxidation, dissociation, and adsorption in Hanford sediments. (submitted) Biogeochemistry of Chelating Agents, J.M. VanBriesen, and B. Nowack, (eds.), American Chemical Society, Washington, D.C.

\section{Abstracts and Presentations:}

Jardine, P.M. 1999. Fate and Transport of Radionuclides Beneath the Hanford Tank-Farms: Unraveling Coupled Geochemical and Hydrological Processes in the Vadose Zone. Workshop on Hanford Tank Farm Needs, Environmental Management Science Program, Pacific Northwest National Laboratory. October, 1999, Richland, WA.

Jardine, P.M., S.C. Brooks, S.E. Fendorf, C.C. Ainsworth, and B.N. Bjornstad. 2000. Fate and Transport of Radionuclides Beneath the Hanford Tank-Farms: Unraveling Coupled Geochemical and Hydrological Processes in the Vadose Zone. Environmental Management Science Program National Meeting, April 24-27, 2000, Atlanta, GA. 
Jardine, P.M. Reactive chemical transport in intact media. Workshop on "Subsurface processes at the mesoscale" to evaluate research direction and facility needs in support of the DOE Environmental Management Program. Idaho National Engineering and Environmental Laboratory. May 8-9, 2000, Salt Lake City, UT. (Invited).

Bostick, B.C., S.E. Fendorf, M.O. Barnett, P.M. Jardine, and S.C. Brooks. 2000 Uranyl Surface Species Formed During Reactive Transport Through Subsurface Media. Soil Science Society of America. Nov. 5-9, 2000, Minneapolis, Minnesota.

Mayes, M.A., P.M. Jardine, T.L. Mehlhorn, J.L. Ladd. 2000. Solute displacement through variably saturated laminated silts and sands from arid regions. Geological Society of America. Nov. 9-18, 2000, Reno, Nevada.

Mayes, M.A., Jardine, P.M., Fendorf, S.E., Mehlhorn, T.L., and Bjornstad, B.N. 2001. Hydrologic and geochemical processes controlling the transport of uranium and cesium through the Hanford vadose zone. American Chemical Society. Chicago, Aug. 26-30.

Mayes, M.A., P.M. Jardine, T.L. Mehlhorn, M.N. Pace, and B.N. Bjornstad. 2001. Hydrologic processes controlling the transport of radionuclides through the Hanford vadose zone. Unsaturated Zone Interest Group workshop. USGS, DOE, and University of Idaho. Idaho Falls, Idaho July 30 - August 2.

Pace, M.N., P.M. Jardine, M.A. Mayes, T.L. Mehlhorn, and J.M. Zachara. 2001. Unsaturated contaminant transport in undisturbed cores from the Hanford formation, Richland, WA. Unsaturated Zone Interest Group Meeting. July 29 - August 2. Idaho Falls, ID.

Mayes, M.A., P.M. Jardine, T.L. Mehlhorn, M.N. Pace, Y. Roh, J.L. Ladd, and B.N. Bjornstad. 2001. Hydrologic processes controlling the transport of radionuclides through the Hanford vadose zone. Soil Science Society of America. October 21-25, Charlotte, NC.

Pace, M.N., P.M. Jardine, M.A. Mayes, T.L. Mehlhorn, Y. Roh, J.L. Ladd, and J.M. Zachara. 2001. Unsaturated contaminant transport in undisturbed cores from the Hanford formation, Richland, WA. Soil Science Society of America. October 21-25, Charlotte, NC.

Mayes, M.A. , P.M. Jardine, M.N. Pace, S.E. Fendorf, T.L. Mehlhorn, Y. Roh, J.L. Ladd, B.N. Bjornstad 2001. Hydrologic Processes Controlling the Transport of Radionuclides Through the Hanford Vadose Zone. American Geophysical Union. December 10-14, San Francisco, CA.

Roh, Y., M.A. Mayes, M.N. Pace, S. Choi, J. Chorover, D.H. Phillips, and P.M. Jardine. 2002. Mineralogical characteristics of sediments at Hanford site, Washington. $39^{\text {th }}$ annual meeting of The Clay Minerals Society, June 8-12, Boulder, CO.

Jardine, P.M. 2002. Soil Chemistry Needs and Expectations at National Laboratory Facilities. Soil Science Society of America, Nov. 10-14, 2002, Indianapolis, IN (Invited).

Mayes, M.A., P.M. Jardine, M. N. Pace, T.L. Mehlhorn, and J.M. Zachara. 2002. The Effects of Unstable Flow on Uranium Transport In Variably Saturated Undisturbed Cores. Soil Science Society of America, Nov. 10-14, Indianapolis, IN. 
Pace, M.N., M.A. Mayes, P.M. Jardine, T.L. Mehlhron, X. Yin, and J.M. Zachara. 2002. Strontium and Uranium Transport through Variably Saturated Undisturbed Cores from the Hanford Formation, Richland, WA. Soil Science Society of America, Nov. 10-14, Indianapolis, IN.

Mayes, M.A., Jardine, P.M., Fendorf, S.E., Pace, M.N., Yin, X., Bjornstad, B.N., and Zachara, J.M. 2003. Fate and Transport of Radionuclides Beneath the Hanford Tank Farms: Unravelling Coupled Geochemical and Hydrologic Processes in the Vadose Zone. FY2003 EMSP Principal Investigator Workshop, May 6-7, Richland, WA.

Mayes, M.A., P.M. Jardine, S.E. Fendorf, M.N. Pace, X. Yin, T.L. Mehlhorn, and J.M. Zachara. 2003. Coupled Hydrological and Geochemical Processes Governing the Fate and Transport of Radionuclides and Toxic Metals in the Hanford Vadose Zone. Division of Environmental Chemistry for the 225th ACS National Meeting, March 23-27, New Orleans, LA.

Pace, M.N., M.A. Mayes, P.M. Jardine, S.E. Fendorf, T. L. Mehlhorn, X. Yin, J. L. Ladd, J. Teerlink, J.M. Zachara. 2003. Contaminant transport through subsurface material from the DOE Hanford reservation. Division of Environmental Chemistry for the 225th ACS National Meeting, March 23-27, New Orleans, LA.

Yin, X; Mayes, M.A.; Pace, M.N.; Jardine, P.M.; Fendorf, S.E.; Mehlhorn, T.L. 2003. Kinetics and mechanisms of metal-EDTA oxidation, dissociation and adsorption on subsurface soils from the Hanford vadose zone. American Chemical Society National Meeting, New York, NY. September 7-11.

Mayes, M.A., Yin, X., Pace, M.N., and Jardine, P.M. 2003. Coupled hydrology and geochemistry of chelated metals in intact Hanford and ORNL subsurface sediments. American Chemical Society, September 7-11, New York, NY.

Pace, M.N, M.A. Mayes, P.M. Jardine, X. Yin, T.L. Mehlhorn. 2003. Unsaturated Transport of Uranium in Undisturbed Cores from the Hanford Site Vadose Zone. Unsaturated Zone Interest Group Meeting, Richland, WA, October 8-9.

Mayes, M.A., Pace, M.N., Yin, X., Jardine, P.M., Fendorf, S.E., and Bjornstad, B.N. 2003. Coupled hydrogeochemical processes controlling the transport of $U$ and chelated metals through the Hanford vadose zone. 9th Biannual Unsaturated Zone Interest Group meeting, October 8-10, Richland, WA.

Pace, M.N., M.A. Mayes, P.M. Jardine, X. Yin, T.L. Mehlhorn. 2003. Unsaturated Transport of Uranium in Undisturbed Cores from the Hanford Site Vadose Zone. The Geological Society of America Annual Meeting, Seattle, WA, November 2-6. 


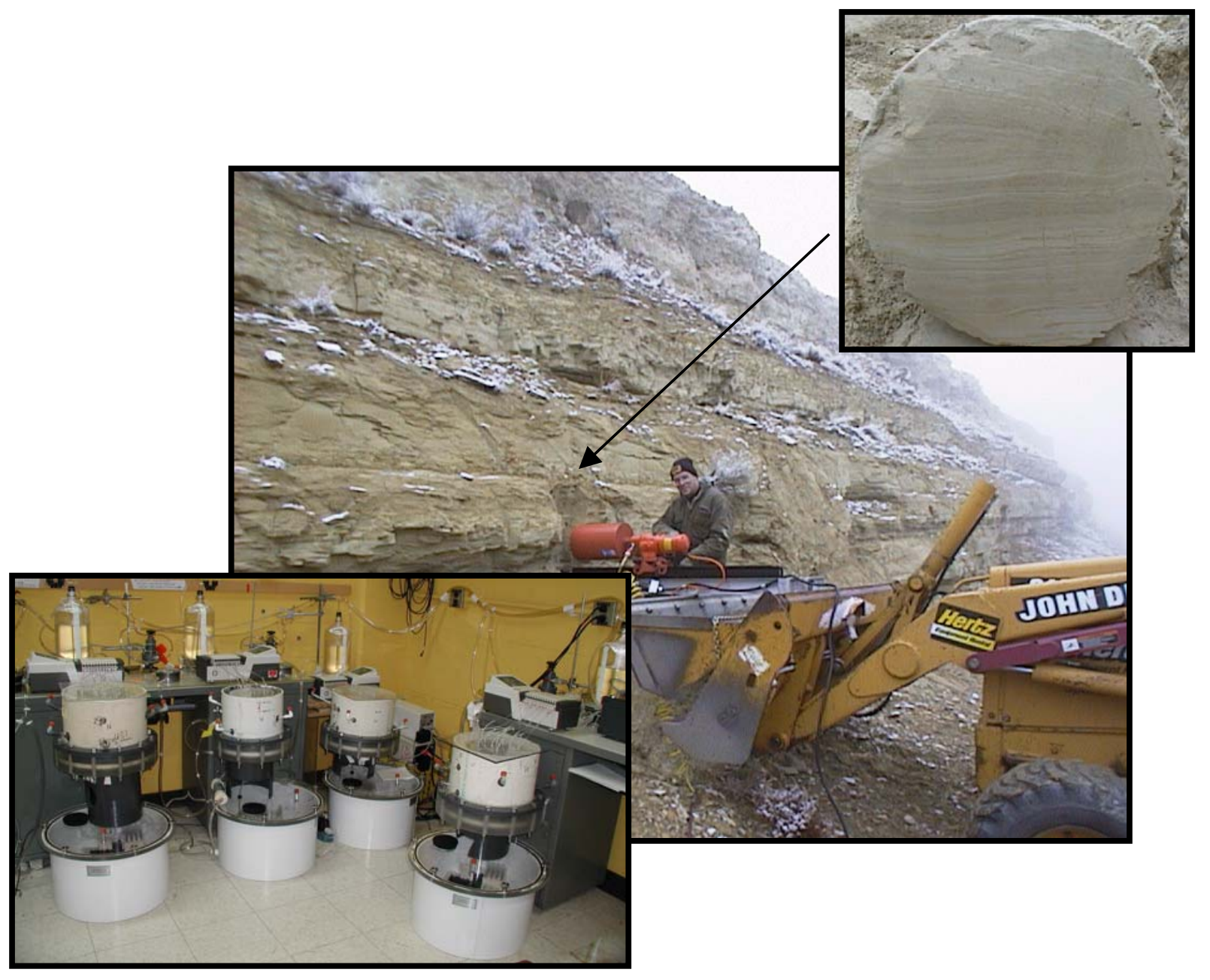

